\title{
MINERAL AND ANTINUTRIENT CONTENT OF HIGH QUALITY CASSAVA-TIGERNUT COMPOSITE FLOUR EXTRUDED SNACK
}

\author{
A.A. ADEBOWALE ${ }^{1,5}$, S.T. KAREEM ${ }^{1}$, O.P. SOBUKOLA ${ }^{1}$, M.A. ADEBISI ${ }^{3}$, A.O. OBADINA ${ }^{1}$, \\ O.E. KAJIHAUSA ${ }^{1}$, M.O. ADEGUNWA ${ }^{2}$, L.O. SANNI ${ }^{1}$ and T. KEITH ${ }^{4}$ \\ ${ }^{1}$ Department of Food Science and Technology, Federal University of Agriculture, Abeokuta, Nigeria \\ ${ }^{2}$ Department of Hospitality and Tourism, Federal University of Agriculture, Abeokuta, Nigeria \\ ${ }^{3}$ Department of Plant Breeding and Seed Technology, Federal University of Agriculture, Abeokuta, Nigeria \\ ${ }^{4}$ Natural Resources Institute, University of Greenwich, Greenwich, UK
}

${ }^{5}$ Corresponding author.

TEL: +234-8034404207;

FAX: +234-39-243045:

EMAIL: rasaq_adebo@yahoo.com

\begin{abstract}
This study investigated the mineral and antinutrient composition of extruded snack produced from different blends of high quality cassava and tigernut flour. The extruded snacks were produced using a single-screw laboratory extruder at constant feed moisture (27\%), screw speed $(60 \mathrm{rpm})$ and barrel temperature (80C). It was observed that the extrudates had higher values for mineral composition (phosphorus, calcium, magnesium, potassium and iron) than the composite flour which showed that extrusion cooking improves the absorption of the minerals. The antinutrient (tannin, phytate, saponin, oxalate, alkaloids and total phenolic) contents of all the flour blends significantly $(P<0.05)$ increased with tigernut flour inclusion. Extrusion cooking resulted in significant $(P<0.05)$ reduction in the antinutrients of the extrudates. The study showed that extrusion cooking reduced the antinutritional factors thereby increasing the bioavailabilty of minerals. Also, the minerals were not affected by the extrusion cooking process probably because minerals are heat stable.
\end{abstract}

\section{PRACTICAL APPLICATIONS}

Findings from this study have potentials to increase the productivity and value addition to tigernut, an underutilized plant specie. The snack produced is also a good alternative gluten free product.

\section{INTRODUCTION}

Consumption of food that are safe, nutritious and hygienically prepared is now on the increase in most part of the world. In food processing, extrusion cooking combines heating with the act of extrusion to create a shaped cooked product. With the help of shear energy, exerted by the rotating screw, and additional heating of the barrel, the food material is heated to its melting point or plasticating point. Some essential nutrients can be retained or enhanced through the process of extrusion cooking. Extrussion cooking have also been reported to partially/totally eliminate or inactivate many antinutritional components of plant foods (Shimelis and Rakshit 2007; Anton et al. 2009; Batista et al. 2010). It also reduces the operating costs and higher productivity than other cooking process, combining energy efficiency and versatility.
In the developing world, cassava (Manihot esculenta Crantz) is a major root crop and an important staple food for over 500 million people (Falade and Akingbala 2010). It has been regarded as a chief source of dietary food energy for the majority of the people living in the lowland tropics, and much of the subhumid tropics of West and Central Africa (Tsegai and Kormawa 2002). High quality cassava flour (HQCF) is unfermented, smooth, odorless, white or creamy flour, bland with no gluten. As a result of increase in the price of wheat in the international market and unfavorable exchange rates in West Africa, HQCF was introduced and is now gradually gaining popularity in the subregion. Commercial production of HQCF is relatively new in Africa and is still being used mainly by small and medium-scale processors (Dziedzoave et al. 2006). 
Tigernut (Cyperus esculentus) is an underutilized crop in the family of Cyperaceae, which produces rhizomes from the base, and tubers that are somewhat spherical. It grows mainly in the middle belt and in the northern regions of Nigeria. It is a root crop which grows widely in wet places as a grass and is sometimes cultivated for its small and sweet tubers (Eteshola and Oraedu 1996). It has been recognized for their health benefits as they rich in fiber, protein and natural sugars, minerals (phosphorus, potassium) (Belewu and Belewu 2007). Tigernut flour has a distinct sweet taste, which is ideal for wide uses. It is a good alternative to many other flours like wheat flour, as it is gluten free and good for people who cannot take gluten in their diets.

Good nutrition indicates that all the nutrients are provided and utilized in adequate amount to maintain optimal health and well-being (Thomas 2006). The ability of extrussion cooking to process various plant food commodities (either alone or in blends) into foods of high-nutritional value has been reported (Anuonye et al. 2010). Antinutrients are natural or synthetic compounds that interfere with the absorption of nutrients. Extrusion cooking has been reported to be a useful process for the reduction of the activity of some antinutritional factors (Mouquet et al. 2003). These antinutrients such as tannin, alkaloids, phytates and saponins might produce adverse effects in humans and animals nutrition (MartinCabrejas et al. 2004; Anton et al. 2009; Batista et al. 2010). Hence, this study was aimed at determining the mineral and antinutritional factor content of extruded snack from high quality cassava and tigernut composite flour.

\section{MATERIALS AND METHODS}

Yellow variety of tigernut seeds were purchased from an open market in Abeokuta, Ogun state, Nigeria while yellowflesh cassava roots (clone 01/1368) were obtained from the Research Farm of the International Institute of Tropical Agriculture (IITA), Ikenne, Nigeria.

\section{TIGERNUT SEED FLOUR AND HQCF PROCESSING}

Tigernut seeds were sorted to remove unwanted materials prior to washing with clean water. The cleaned seeds were dried in a cabinet dryer (Genlab, DC500, UK) at 60C for $72 \mathrm{~h}$ to reduce moisture to $13 \%$ (modified method of AdeOmowaye et al. 2008). Dry seeds were milled using a laboratory hammer mill and then sieved using a $600 \mu \mathrm{m}$ screen. The tigernut flour was then packed in zip-lock polyethylene bag and stored at $4 \mathrm{C}$ until used.

Yellow fleshed cassava roots were peeled, washed, grated, dewatered and then dried in a cabinet dryer (Genlab, DC500, $\mathrm{UK}$ ) at $50 \mathrm{C}$ for $6 \mathrm{~h}$, the dried grits were milled and then sieved using $250 \mu \mathrm{m}$ screen (Dziedzoave et al. 2003). The flour was
TABLE 1. FORMULATION OF DIFFERENT BLENDS OF HQCF-TIGERNUT FLOUR

\begin{tabular}{ll}
\hline HQCF $(\%)$ & Tigernut flour $(\%)$ \\
\hline 100 & 0 \\
90 & 10 \\
80 & 20 \\
70 & 30 \\
60 & 40 \\
50 & 50 \\
40 & 60 \\
30 & 70 \\
20 & 80 \\
0 & 100 \\
\hline
\end{tabular}

packaged in zip-lock polyethylene bag and stored at 4C until used. The HQCF and tigernut flour obtained were blended together in different proportions using a laboratory blender (Philip, HR2020/50, UK) as shown in Table 1.

\section{Processing of Extruded Snacks}

This was processed following the procedure of Kareem et al. (2015). One hundred grams (100 g) each of the various composite flour samples (Table 1) were mixed with other ingredients (i.e., $0.75 \%$ dried onion powder, $0.3 \%$ dried ginger powder, $0.75 \%$ iodized salt, $7.5 \%$ sugar, $21 \%$ milk powder and $0.3 \%$ dried chilli pepper powder). The mixture (feed samples) were preconditioned to $27 \%(\mathrm{wb})$ moisture content with the addition of $50 \mathrm{~mL}$ hot water (80-90C), mixed and allowed to stand for 2 min to uniformly hydrate the raw material in order to eliminate any dry core. A laboratory scale single-screw extruder with screw length per diameter, screw diameter and length of 16.43:1, $18.5 \mathrm{~mm}$ and $304 \mathrm{~mm}$, respectively, was used. The extruder composed of two sections: the transmission and the die zones. The barrel section was heated with band heater (Sobukola et al. 2012). It was operated at full speed in all runs under the following constant conditions: barrel and die temperature (80C), screw speed $(60 \mathrm{rpm})$ and feed moisture $(27 \% \mathrm{wb})$. Flat die of $15 \mathrm{~mm}$ width was used to produce nonexpanded extrudates. The extrudates were cut into small pieces of $2 \mathrm{~cm}$ length and dried in a hot air oven (Genlab, OV/50/ DIG, UK) at $60 \mathrm{C}$ for $3 \mathrm{~h}$ to obtain the HQCF-tigernut seed composite flour extruded snacks. The snack was cooled to room temperature, packaged in zip-lock polyethylene bags and stored at $4 \mathrm{C}$ for further analysis.

\section{DETERMINATION OF THE MINERAL COMPOSITION OF THE COMPOSITE FLOUR AND EXTRUDED SNACKS}

The mineral contents of the samples were determined by the procedure of AOAC (2000). Calcium, potassium, 
magnesium, phosphorus and iron elements were measured with Atomic Absorption Spectrophotometer (Thermo scientific S Series Model GE 712354) after digesting with perchloric-nitric acid mixture (AOAC 2000). Prior to digestion, $0.5 \mathrm{~g}$ of the samples were weighed into a $125 \mathrm{~mL}$ Erlenmeyer flask with the addition of perchloric acid (4 mL), concentrated $\mathrm{HNO}_{3}(25 \mathrm{~mL})$ and concentrated sulfuric acid $(2 \mathrm{~mL})$ under a fume hood. The contents were mixed and heated gently in a digester (Buchi Digestion unit K-424) at low to medium heat on a hot plate under perchloric acid fume hood and heating was continued until dense white fume appeared. Heating was continued strongly for half a minute and then allowed to cool followed by the addition of $50 \mathrm{~mL}$ distilled water. The solution was allowed to cool and filtered completely with a wash bottle into a Pyrex volumetric flask and then made up with distilled water. The solution was then read on Atomic Absorption Spectrophotometer.

\section{DETERMINATION OF ANTINUTRITIONAL FACTOR COMPOSITION}

Alkaloids. This was done by the alkaline precipitation gravimetric method described by Harborne (1973). A measured weight of the sample was dispersed in 10\% acetic acid solution in ethanol to form a ratio of 1:10 (10\%). The mixture was allowed to stand for $4 \mathrm{~h}$ at $28 \mathrm{C}$. It was later filtered via Whatman No. 1 filter paper. The filtrate was concentrated to one quarter of its original volume by evaporation and treated with drop wise addition of concentrated aque- ous $\mathrm{NH}_{4} \mathrm{OH}$ until the alkaloid was precipitated. The precipitated alkaloid was received in a weighed filter paper, washed with $1 \%$ ammonia solution and dried in the oven at $80 \mathrm{C}$. Alkaloid content was calculated and expressed as a percentage of the weight of sample analyzed.

Tannins. The method of Swain (1979) was used for the determination of tannin contents of the composite flour and extrudates. About $0.2 \mathrm{~g}$ of finely ground sample was measured into a $50 \mathrm{~mL}$ beaker. Then, $20 \mathrm{~mL}$ of $50 \%$ methanol was added, covered with parafin and placed in a water bath at $77-80 \mathrm{C}$ for $1 \mathrm{~h}$ with continuous stirring using a glass rod to prevent lumping. The extract was quantitatively filtered using a double-layered Whatman No.1 filter paper into a $100 \mathrm{~mL}$ volumetric flask using 50\% methanol to rinse. This was made up to mark with distilled water and thoroughly mixed. Then, $1 \mathrm{~mL}$ of sample extract was pipetted into $50 \mathrm{~mL}$ volumetric flask, $20 \mathrm{~mL}$ of distilled water, $2.5 \mathrm{~mL}$ of Folin-Denis reagent and $10 \mathrm{~mL}$ of $17 \% \mathrm{Na}_{2} \mathrm{CO}_{3}$ were added and mixed properly. The mixture was made up to mark with distilled water, mixed well and allowed to stand for $20 \mathrm{~min}$ when a bluish-green coloration developed. Standard tannic acid solutions of range 0-10 ppm were treated similarly as $1 \mathrm{~mL}$ of the sample. The absorbance of the tannic acid standard solutions as well as samples was read after color development on a Spectronic 21D Spectrophotometer at a wavelength of $760 \mathrm{~nm}$.

Percentage tannin was calculated using the formula below:

$$
\text { Tannin }(\%)=\frac{\text { Absorbance of sample } \times \text { Average gradient } \times \text { Dilution factor }}{\text { weight of sample } \times 10,000}
$$

Saponin. The spectrophotometric method of Brunner (1984) was used for saponin analysis. One gram of finely ground sample was weighed into a $250 \mathrm{~mL}$ beaker and $100 \mathrm{~mL}$ isobutyl alcohol was added. The mixture was shaken on a UDY shaker for $5 \mathrm{~h}$ to ensure uniform mixing. Thereafter, the mixture was filtered through a Whatman No. 1 filter paper into a $100 \mathrm{~mL}$ beaker and $20 \mathrm{~mL}$ of $40 \%$ saturated solution of magnesium carbonate added. The mixture obtained with saturated $\mathrm{MgCO}_{3}$ was again filtered through a Whatman No. 1 filter paper to obtain a clear colorless solution. Then, $1 \mathrm{~mL}$ of the colorless solution was pipetted into $50 \mathrm{~mL}$ volumetric flask and $2 \mathrm{~mL}$ of $5 \% \mathrm{FeCl}_{3}$ solution was added and made up to mark with distilled water. It was allowed to stand for $30 \mathrm{~min}$ for blood red color to develop. Then, $0-10$ ppm standard saponin solutions were prepared from saponin stock solution. The standard solutions were treated similarly with $2 \mathrm{~mL}$ of $5 \% \mathrm{FeCl}$ solution. The absorbance of the sample as well as standard saponin solutions were read after color development on a T60 UV-visible spectrophotometer, U.K. at a wavelength of $380 \mathrm{~nm}$. Percentage saponin was calculated using the formula below:

$$
\text { Saponin }(\%)=\frac{\text { Absorbance of sample } \times \text { Average gradient } \times \text { Dilution factor }}{\text { weight of sample } \times 10,000}
$$


Total Phenol. The total phenol content of the samples was determined using the method described by Malick and Singh (1980). Each sample (1 g) was taken and ground in $10 \mathrm{~mL}$ of $80 \%$ ethanol using a pestle and mortar. This homogenate was centrifuged at 10,000 rpm for 20 min. Supernatant was saved and residue was reextracted with $10 \mathrm{~mL}$ of $80 \%$ ethanol, centrifuged and the supernatant was saved. The supernatant was evaporated to dryness. The residue was dissolved in $5 \mathrm{~mL}$ distilled water. Different quantities of samples $(0.2-2 \mathrm{~mL})$ were taken in the test tubes. Volume of each tube was made to $3 \mathrm{~mL}$ with distilled water. Folin-Ciocalteu reagent $(0.5 \mathrm{~mL})$ was added in each tube. After $3 \mathrm{~min}, 2 \mathrm{~mL}$ sodium carbonate (20\%) solution was added to each tube. The contents of the tubes were mixed thoroughly and the tubes were placed in boiling water bath exactly for $1 \mathrm{~min}$, cooled and the absorbance was measured at $650 \mathrm{~nm}$ against a blank reagent. Standard curve was prepared by using different concentrations of catechol.

Oxalate. Oxalate was determined using method described by Day and Underwood (1986). One gram of the sample was weighed into $100 \mathrm{~mL}$ conical flask after which $75 \mathrm{~mL}$ of $3 \mathrm{~N} \mathrm{H}_{2} \mathrm{SO}_{4}$ was added and stirred intermittently with a magnetic stirrer for $1 \mathrm{~h}$. It was then filtered using Whatman No. 1 filter paper. From the filtrate, $25 \mathrm{~mL}$ aliquot was taken and titrated while hot (80-90C) against $0.1 \mathrm{~N} \mathrm{KMnO}_{4}$ solution until a faint pink color persisted for at least $30 \mathrm{~s}$.

$$
\text { Oxalate content }=\frac{T \times(V m e)(D f) \times 105}{M E \times M_{f}} \mathrm{mg} / 100 \mathrm{~g}
$$

$T=$ titre of $\mathrm{KMnO}_{4}(\mathrm{~mL}), V m e=$ volume-mass equivalent, $D f=$ dilution factor $\left(V_{T} / A \times 2.4\right.$, where $V_{T}$ is the total volume of titrate and $A$ is the aliquot used), $M E$ is the molar equivalent of $\mathrm{KMnO}_{4}$ in oxalate, $M_{f}=$ mass of flour.

Phytate. Phytate was determined using the method described by Maga (1982). Two grams of each finely ground flour sample was soaked in $20 \mathrm{~mL}$ of $0.2 \mathrm{~N} \mathrm{HCl}$ for $3 \mathrm{~h}$ and filtered. After filtration, $0.5 \mathrm{~mL}$ of the filtrate was mixed with $1 \mathrm{~mL}$ ferric ammonium sulfate solution in a test tube, boiled for $30 \mathrm{~min}$ in a water bath, cooled in ice for $15 \mathrm{~min}$ and centrifuged at $3000 \mathrm{rpm}$ for $15 \mathrm{~min}$. One milliliter of the supernatant was mixed with $1.5 \mathrm{~mL}$ of 2,2-pyridine solution and the absorbance read in a spectrophotometer at $519 \mathrm{~nm}$. The concentration of phytic acid was obtained by extrapolation from a standard curve using standard phytic acid solution.

Hydrogen Cyanide. Quantitative determination of hydrogen cyanide was carried out using the method described by Essers et al. (1993). An extract was made from the flour blends and extrudates using cold orthophosphoric acid. The extract was treated with an excess amount of exogenous linamarase; the $\mathrm{pH}$ was raised to convert all cyanohydrins and hydrogen cyanide to cyanide ions. Cyanide ions were quantified using a specific and stoichiometric reaction with chloramine $\mathrm{T}$, isonicotinate and dimethyl barbituric, which produces a colored dye. The absorbance of the color produced is proportional to the concentration of cyanide ions in the reaction mixture.

\section{Statistical Analysis}

Data obtained were subjected to Analysis of Variance (ANOVA) using SPSS version 16.0 and the differences between significant mean values were evaluated at $P<0.05$ probability level using Duncan's Multiple Range Test.

\section{RESULTS AND DISCUSSION}

\section{Mineral Composition of Composite Flour and Extruded Snack}

Tables 2 and 3 show the result of mineral composition of composite flour and extrudate. It was observed that the mineral content of the extrudates was generally higher than that of the flour blends. It has been reported that increase in extrusion temperature could lead to increase in amount of trace elements in extruded products (Anuoye et al. 2010). The 100\% HQCF had the lowest value while 100\% tigernut flour had the highest value for all the minerals. The Potassium content of the flour ranged from $45.98 \pm 0.43$ to $121.1 \pm 1.54 \mathrm{mg} / 100 \mathrm{~g}$ while that of the extrudates ranged from $55.55 \pm 2.89$ to $125.29 \pm 2.62 \mathrm{mg} / 100 \mathrm{~g}$. The magnesium content of the flour blends ranged from $9.40 \pm 0.86$ to $10.58 \pm 0.10 \mathrm{mg} / 100 \mathrm{~g}$, while that of the extrudates ranged from $9.68 \pm 0.42$ to $19.53 \pm 0.97 \mathrm{mg} / 100 \mathrm{~g}$. The phosphorus content of the flour blends ranged from $55.0 \pm 14.14$ to $171.4 \pm 1.94 \mathrm{mg} / 100 \mathrm{~g}$ while that of the extrudates ranged from $85.0 \pm 0.02$ to $185.0 \pm 7.01 \mathrm{mg} / 100 \mathrm{~g}$. The phosphorus content of $100 \%$ tigernut flour $(171.4 \mathrm{mg} / 100 \mathrm{~g})$ was higher than the value of $121 \mathrm{mg} / 100 \mathrm{~g}$ reported by Oladele and Aina (2007). The value obtained for 100\% HQCF (55 mg/ $100 \mathrm{~g}$ ) was higher than the value of $52 \mathrm{mg} / 100 \mathrm{~g}$ reported by Sarkiyayi and Agar (2010). Minerals are heat stable and unlikely to be lost during extrusion. The phosphorus content of high quality cassava-tigernut flour and extruded samples were higher than the daily requirement for adults (30 mg/100 g).

The calcium content of the flour blends ranged from $138.0 \pm 6.81$ to $214.3 \pm 7.44 \mathrm{mg} / 100 \mathrm{~g}$ while that of the extrudates ranged from $305.0 \pm 21.2$ to $382.0 \pm 7.07 \mathrm{mg} /$ 
TABLE 2. MINERAL COMPOSTION OF HIGH QUALITY CASSAVA-TIGERNUT FLOUR BLENDS (mg/100 g)

\begin{tabular}{|c|c|c|c|c|c|}
\hline Sample & $\mathrm{P}$ & $\mathrm{Ca}$ & $\mathrm{Mg}$ & K & $\mathrm{Fe}$ \\
\hline $100 \%$ CF & $55.0 \pm 14.14^{b}$ & $138.0 \pm 6.81^{f}$ & $9.40 \pm 0.86^{a}$ & $45.98 \pm 0.43^{f}$ & $1.67 \pm 0.24^{b}$ \\
\hline $90 \%$ CF:10\%TF & $60.0 \pm 7.07^{b}$ & $154.8 \pm 2.66^{\mathrm{e}}$ & $10.42 \pm 0.58^{a}$ & $54.05 \pm 6.20^{\mathrm{ef}}$ & $1.71 \pm 0.20^{b}$ \\
\hline $80 \%$ CF:20\%TF & $87.1 \pm 4.18^{a b}$ & $169.0 \pm 10.39^{d}$ & $10.36 \pm 0.66^{a}$ & $64.31 \pm 7.05^{\mathrm{def}}$ & $1.79 \pm 0.20^{b}$ \\
\hline $70 \%$ CF:30\%TF & $101.0 \pm 4.24^{\mathrm{ab}}$ & $176.1 \pm 4.37^{\mathrm{cd}}$ & $10.52 \pm 0.56^{a}$ & $73.35 \pm 9.52^{\text {cdef }}$ & $1.84 \pm 0.13^{b}$ \\
\hline $60 \%$ CF:40\% TF & $105.0 \pm 12.8^{a b}$ & $179.5 \pm 5.34^{b c d}$ & $10.22 \pm 1.08^{a}$ & $82.50 \pm 16.63^{\text {bcde }}$ & $1.84 \pm 0.14^{b}$ \\
\hline $50 \%$ CF:50\% TF & $116.4 \pm 1.94^{\mathrm{ab}}$ & $181.2 \pm 14.18^{\mathrm{bcd}}$ & $10.15 \pm 0.15^{a}$ & $94.62 \pm 9.58^{\mathrm{abcd}}$ & $2.10 \pm 0.25^{a b}$ \\
\hline $40 \%$ CF:60\%TF & $132.6 \pm 3.5^{a b}$ & $181.9 \pm 2.41^{b c d}$ & $10.19 \pm 1.12^{a}$ & $99.31 \pm 15.85^{a b c}$ & $2.14 \pm 0.30^{a b}$ \\
\hline $30 \%$ CF:70\%TF & $144.6 \pm 6.4^{\mathrm{ab}}$ & $189.5 \pm 5.43^{b c}$ & $10.33 \pm 0.52^{a}$ & $101.0 \pm 14.85^{\mathrm{abc}}$ & $2.28 \pm 0.28^{a b}$ \\
\hline $20 \%$ CF:80\%TF & $145.2 \pm 7.26^{\mathrm{ab}}$ & $193.6 \pm 4.91^{b}$ & $10.48 \pm 0.08^{a}$ & $109.0 \pm 16.92^{\mathrm{ab}}$ & $2.38 \pm 0.51^{a b}$ \\
\hline $100 \% \mathrm{TF}$ & $171.4 \pm 1.94^{a}$ & $214.3 \pm 7.44^{a}$ & $10.58 \pm 0.10^{a}$ & $121.1 \pm 1.54^{a}$ & $2.72 \pm 0.53^{a}$ \\
\hline
\end{tabular}

Mean values with different superscripts within the same column are significantly different $(P<0.05)$.

CF - HQCF, TF - tigernut flour, P-phosphorus, Ca - calcium, Mg - magnesium, $\mathrm{K}$ - potassium, Fe - iron.

100 g. The calcium content of $100 \%$ tigernut flour $(214.3 \mathrm{mg} / 100 \mathrm{~g})$ was higher than the value of $155 \mathrm{mg} / 100 \mathrm{~g}$ reported by Oladele and Aina (2007). This may probably be due to the differrent location where the sample was cultivated since it has been reported that genetic and environment interactions affects nutritional composition of plant materials (Sanni et al. 2008). The value obtained for $100 \%$ HQCF (138 mg/100 g) was higher than the value (33 mg/ $100 \mathrm{~g})$ reported by Sarkiyayi and Agar (2010). This may likely be due to the improved variety of cassava that was used in this study. The result obtained for calcium was high and this could be due to low level of oxalic acid and phytic acids being the major chelators of calcium, hence releasing calcium for biological activities.

The iron content of the flour ranged from $1.67 \pm 0.24$ to $2.72 \pm 0.53 \mathrm{mg} / 100 \mathrm{~g}$ while that of the extrudates ranged from $1.98 \pm 0.69$ to $4.68 \pm 0.56 \mathrm{mg} / 100 \mathrm{~g}$. The iron content of $100 \%$ tigernut flour $(2.72 \mathrm{mg} / 100 \mathrm{~g})$ was higher than the value of $0.65 \mathrm{mg} / 100 \mathrm{~g}$ reported by Oladele and Aina (2007). The value obtained for $100 \%$ HQCF $(1.67 \mathrm{mg} / 100 \mathrm{~g})$ was higher than the range of values $(0.16-$ $0.24 \mathrm{mg} / 100 \mathrm{~g}$ ) reported by Emmanuel et al. (2012). Iron is required for the synthesis of hemoglobin and myoglobin, which are oxygen carriers in the blood and muscle, respectively. The extrudates had higher values for mineral composition than individual raw samples which showed that extrusion cooking significantly reduced the antinutritional factors especially the chelating agents thereby making more mineral to be available for analysis. It was also reported that minerals content before and after extrusion cooking was significantly $(P<0.05)$ different by Murekatete et al. (2010). This can also be attributed to a hightemperature, short-time process of extrusion cooking, thereby yielding a better product. This trend is in conformity with earlier reports of Harper (1988) and Anuonye et al. (2009).

\section{Antinutritional Composition of Composite Flour and Extruded Snack}

The data on antinutritional composition of the high quality cassava-tigernut flour and its extruded snack are shown in Tables 4 and 5, respectively. It was observed that extrusion cooking caused significant $(P<0.05)$ decrease in these antinutrients. The hydrogen cyanide of high quality cassavatigernut composite flour ranged from $1.13 \pm 0.06$ to $1.22 \pm 0.01 \%$ while that of extrudates ranged from $0.75 \pm 0.01$ to $0.87 \pm 0.03 \%$. The value of hydrogen cyanide

TABLE 3. MINERAL COMPOSTION OF HIGH QUALITY CASSAVA-TIGERNUT EXTRUDATES (mg/100 g)

\begin{tabular}{|c|c|c|c|c|c|}
\hline Sample & $P$ & $\mathrm{Ca}$ & $\mathrm{Mg}$ & K & $\mathrm{Fe}$ \\
\hline $100 \% C F$ & $85.0 \pm 0.02^{a}$ & $305.0 \pm 21.21^{a}$ & $9.68 \pm 0.42^{c}$ & $55.55 \pm 2.89^{e}$ & $1.98 \pm 0.69^{c}$ \\
\hline $90 \%$ CF:10\%TF & $90.0 \pm 0.01^{a}$ & $325.0 \pm 28.57^{a}$ & $10.70 \pm 1.84^{b c}$ & $59.41 \pm 2.85^{\mathrm{e}}$ & $2.16 \pm 0.63^{c}$ \\
\hline $80 \%$ CF:20\%TF & $110.0 \pm 0.00^{b}$ & $339.8 \pm 16.99^{a}$ & $11.70 \pm 0.94^{b c}$ & $61.14 \pm 3.78^{\mathrm{e}}$ & $2.28 \pm 0.52^{c}$ \\
\hline $70 \%$ CF:30\% TF & $110.0 \pm 0.01^{b}$ & $358.0 \pm 20.62^{a}$ & $11.34 \pm 0.69^{b c}$ & $71.75 \pm 3.81^{\mathrm{de}}$ & $2.84 \pm 0.47^{b c}$ \\
\hline $60 \%$ CF:40\%TF & $115.0 \pm 7.07^{b}$ & $345.4 \pm 28.16^{a}$ & $10.51 \pm 1.41^{b c}$ & $78.98 \pm 3.25^{\mathrm{cd}}$ & $2.87 \pm 0.23^{b c}$ \\
\hline $50 \%$ CF:50\%TF & $135.0 \pm 0.17^{c}$ & $360.1 \pm 19.03^{a}$ & $11.00 \pm 1.32^{b c}$ & $83.96 \pm 3.35^{\mathrm{cd}}$ & $2.96 \pm 0.41^{b c}$ \\
\hline $40 \%$ CF:60\%TF & $140.0 \pm 6.10^{\mathrm{cd}}$ & $356.6 \pm 16.80^{a}$ & $12.07 \pm 0.71^{b c}$ & $86.71 \pm 2.85^{\mathrm{cd}}$ & $3.11 \pm 0.09^{b c}$ \\
\hline $30 \%$ CF:70\%TF & $145.0 \pm 3.02^{\mathrm{cd}}$ & $371.2 \pm 15.40^{a}$ & $12.50 \pm 0.17^{b c}$ & $94.16 \pm 1.78^{b c}$ & $3.64 \pm 0.13^{a b}$ \\
\hline $20 \%$ CF:80\%TF & $150.0 \pm 2.18^{d}$ & $370.9 \pm 10.49^{a}$ & $12.88 \pm 0.75^{b}$ & $108.60 \pm 2.44^{b}$ & $3.84 \pm 0.44^{\mathrm{ab}}$ \\
\hline $100 \% \mathrm{TF}$ & $185.0 \pm 7.01^{\mathrm{e}}$ & $382.0 \pm 7.07^{a}$ & $19.53 \pm 0.97^{a}$ & $125.29 \pm 2.62^{a}$ & $4.68 \pm 0.56^{a}$ \\
\hline
\end{tabular}

Mean values with different superscripts within the same column are significantly different $(P<0.05)$.

$\mathrm{CF}-\mathrm{HQCF}, \mathrm{TF}$ - tigernut flour, $\mathrm{P}$ - phosphorus, $\mathrm{Ca}$ - calcium, Mg-magnesium, $\mathrm{K}$ - potassium, Fe - iron. 
TABLE 4. ANTINUTRITIONAL FACTORS OF FLOUR BLENDS (\%)

\begin{tabular}{|c|c|c|c|c|c|c|c|}
\hline Sample & $\mathrm{HCN}$ & Oxalate & Phytate & Tannin & Saponin & Phenolic & Alkaloids \\
\hline $100 \% C F$ & $1.15 \pm 0.01^{\mathrm{cd}}$ & $0.12 \pm 0.01^{i}$ & $0.32 \pm 0.01^{\mathrm{g}}$ & $3.62 \pm 0.04^{e}$ & $0.42 \pm 0.04^{f}$ & $0.57 \pm 0.01^{f}$ & $0.94 \pm 0.06^{i}$ \\
\hline $90 \%$ CF:10\%TF & $1.13 \pm 0.06^{d}$ & $0.22 \pm 0.02^{h}$ & $0.58 \pm 0.04^{f}$ & $3.64 \pm 0.08^{e}$ & $0.47 \pm 0.05^{\mathrm{ef}}$ & $0.67 \pm 0.04^{e}$ & $1.13 \pm 0.08^{h}$ \\
\hline $80 \%$ CF:20\%TF & $1.15 \pm 0.01^{c d}$ & $0.33 \pm 0.02^{g}$ & $0.67 \pm 0.01^{f}$ & $4.27 \pm 0.08^{d}$ & $0.48 \pm 0.04^{\mathrm{ef}}$ & $0.85 \pm 0.03^{d}$ & $1.25 \pm 0.03^{g h}$ \\
\hline $70 \%$ CF:30\%TF & $1.17 \pm 0.03^{b c}$ & $0.41 \pm 0.02^{f}$ & $0.97 \pm 0.04^{d}$ & $4.38 \pm 0.05^{\mathrm{cd}}$ & $0.57 \pm 0.04^{\mathrm{e}}$ & $0.89 \pm 0.01^{c d}$ & $1.35 \pm 0.01^{\mathrm{fg}}$ \\
\hline $60 \% C F: 40 \%$ TF & $1.14 \pm 0.01^{d}$ & $0.47 \pm 0.01^{\mathrm{e}}$ & $0.83 \pm 0.05^{e}$ & $4.40 \pm 0.01^{\mathrm{cd}}$ & $0.76 \pm 0.05^{d}$ & $0.89 \pm 0.05^{\mathrm{cd}}$ & $1.47 \pm 0.03^{e f}$ \\
\hline $50 \%$ CF:50\%TF & $1.18 \pm 0.06^{b}$ & $0.53 \pm 0.03^{\text {de }}$ & $1.03 \pm 0.01^{d}$ & $4.46 \pm 0.08^{c}$ & $1.02 \pm 0.06^{c}$ & $0.90 \pm 0.04^{\mathrm{cd}}$ & $1.49 \pm 0.04^{\text {def }}$ \\
\hline $40 \%$ CF:60\% TF & $1.22 \pm 0.01^{a}$ & $0.56 \pm 0.06^{\mathrm{cd}}$ & $1.02 \pm 0.01^{d}$ & $4.49 \pm 0.09^{c}$ & $1.23 \pm 0.04^{b}$ & $0.91 \pm 0.06^{c}$ & $1.56 \pm 0.10^{\text {cde }}$ \\
\hline $30 \%$ CF:70\%TF & $1.19 \pm 0.01^{b}$ & $0.59 \pm 0.05^{c}$ & $1.38 \pm 0.06^{c}$ & $5.27 \pm 0.06^{b}$ & $1.21 \pm 0.04^{b}$ & $0.91 \pm 0.05^{c}$ & $1.73 \pm 0.07^{\mathrm{ab}}$ \\
\hline $20 \% C F: 80 \%$ TF & $1.17 \pm 0.03^{b c}$ & $0.73 \pm 0.03^{b}$ & $1.49 \pm 0.03^{b}$ & $6.09 \pm 0.10^{a}$ & $1.23 \pm 0.06^{b}$ & $0.99 \pm 0.01^{b}$ & $1.87 \pm 0.12^{\mathrm{a}}$ \\
\hline $100 \% \mathrm{TF}$ & $1.15 \pm 0.02^{\mathrm{cd}}$ & $0.83 \pm 0.03^{a}$ & $1.90 \pm 0.02^{a}$ & $6.05 \pm 0.10^{a}$ & $1.24 \pm 0.06^{a}$ & $1.13 \pm 0.01^{a}$ & $1.68 \pm 0.06^{\mathrm{abc}}$ \\
\hline
\end{tabular}

Values are means of trplicate determination.

Mean values with different superscripts within the same column are significantly different $(P<0.05)$.

CF - HQCF, TF - Tigernut flour.

of all the high quality cassava-tigernut flour and extruded samples were below the Nigerian Industrial Standard $(10 \mathrm{mg} / \mathrm{kg}$ ) for cassava and cassava products (NIS 344:2004) maximum specification for HQCF (Sanni et al. 2005). Initial processing of the raw samples (cassava roots and tigernut seeds) reduced their hydrogen cyanide below the NIS maximum specification before extrusion cooking which further reduced the cyanide content. It has been reported that extrusion cooking affected the hydrogen cyanide content of (shreaded cassava chips) Ighu/AYB (Africa Yam Bean) blends (Omeire et al. 2012). Hydrogen cyanide is heat labile and hence can volatilize while subjecting the sample to extrusion process (Iorgyer et al. 2009).

The oxalate content of high quality cassava-tigernut flour blends ranged from $0.12 \pm 0.01$ to $0.83 \pm 0.03 \%$ while that of the extrudates ranged from $0.11 \pm 0.01$ to $0.63 \pm 0.11 \%$. The oxalate content of $100 \%$ tigernut flour $(0.83 \%)$ was higher than the range of values $(0.41-0.52 \%)$ reported by Nwaoguikpe (2010). The value obtained for $100 \%$ HQCF $(0.12 \%)$ was higher than the value $0.02 \%$ reported by Sarkiyayi and Agar (2010). Oxalates can remove calcium in the form of calcium oxalate in the blood and thus may result to kidney damage and they also exhibit structure dependent biological activity (Savage 1993).

The phenolic content of high quality cassava-tigernut flour blends ranged from $0.57 \pm 0.01$ to $1.13 \pm 0.01 \%$ while that of the extrudates ranged from $0.37 \pm 0.01$ to $1.00 \pm 0.18 \%$. The phenolic content of $100 \%$ tigernut flour $(1.13 \%)$ was higher than the value of $1.00 \pm 0.07 \%$ reported by Oladele et al. (2009). Recent finding has shown that phenolic compounds are powerful antioxidants that can protect the human body from free radicals, the formation of which is associated with the normal metabolism of aerobic cells (Oboh and Rocha 2007).

Alkaloids, saponins and tannins are known to have antimicrobial activity, as well as other physiological activities in human system (Sofowora 1993; Evans 2005). The alkaloids content of high quality cassava-tigernut flour blends ranged from $0.94 \pm 0.06$ to $1.87 \pm 0.12 \%$ while that of the extrudates ranged from $0.87 \pm 0.06$ to $1.74 \pm 0.03 \%$. The result obtained for alkaloids content of $100 \%$ tigernut (1.89\%) was low compared to the value $(2.63 \%)$ reported by Oladele et al. (2009) and this may likely be due to varietal differences. Alkaloids are known for their toxicity, but not all

TABLE 5. ANTINUTRITIONAL FACTORS OF HIGH QUALITY CASSAVA-TIGERNUT EXTRUDATES (\%)

\begin{tabular}{|c|c|c|c|c|c|c|c|}
\hline Sample & $\mathrm{HCN}$ & Oxalate & Phytate & Tannin & Saponin & Phenolic & Alkaloids \\
\hline $100 \% C F$ & $0.87 \pm 0.03^{a}$ & $0.11 \pm 0.01^{g}$ & $0.27 \pm 0.02^{f}$ & $2.68 \pm 0.01^{c}$ & $0.34 \pm 0.05^{d}$ & $0.37 \pm 0.01^{d}$ & $0.87 \pm 0.06^{\mathrm{e}}$ \\
\hline $90 \%$ CF:10\%TF & $0.84 \pm 0.01^{a}$ & $0.18 \pm 0.03^{\mathrm{fg}}$ & $0.47 \pm 0.03^{e f}$ & $2.46 \pm 0.10^{c}$ & $0.38 \pm 0.04^{d}$ & $0.51 \pm 0.05^{d}$ & $1.12 \pm 0.06^{\mathrm{de}}$ \\
\hline $80 \%$ CF:20\%TF & $0.81 \pm 0.01^{b}$ & $0.30 \pm 0.01^{e f}$ & $0.61 \pm 0.01^{\mathrm{de}}$ & $3.19 \pm 0.04^{\mathrm{ab}}$ & $0.43 \pm 0.04^{d}$ & $0.61 \pm 0.11^{b c d}$ & $1.22 \pm 0.05^{d}$ \\
\hline $70 \%$ CF:30\%TF & $0.78 \pm 0.03^{b}$ & $0.33 \pm 0.06^{\text {def }}$ & $0.76 \pm 0.02^{c d}$ & $3.32 \pm 0.08^{a b}$ & $0.52 \pm 0.08^{c d}$ & $0.64 \pm 0.12^{b c d}$ & $1.28 \pm 0.07^{\mathrm{cd}}$ \\
\hline $60 \%$ CF:40\%TF & $0.75 \pm 0.01^{a}$ & $0.40 \pm 0.03^{\mathrm{cde}}$ & $0.79 \pm 0.02^{\mathrm{cd}}$ & $3.72 \pm 0.03^{a b}$ & $0.71 \pm 0.08^{c}$ & $0.75 \pm 0.05^{a b c}$ & $1.37 \pm 0.05^{\mathrm{cde}}$ \\
\hline $50 \%$ CF:50\%TF & $0.82 \pm 0.01^{b}$ & $0.43 \pm 0.02^{\text {bcde }}$ & $0.88 \pm 0.01^{c d}$ & $3.85 \pm 0.01^{a b c}$ & $0.93 \pm 0.05^{b}$ & $0.77 \pm 0.07^{a b c}$ & $1.40 \pm 0.06^{b c d e}$ \\
\hline $40 \%$ CF:60\%TF & $0.85 \pm 0.02^{a}$ & $0.49 \pm 0.02^{a b c d}$ & $1.01 \pm 0.01^{b c}$ & $4.38 \pm 0.04^{a b}$ & $1.04 \pm 0.04^{b}$ & $0.86 \pm 0.03^{a b}$ & $1.52 \pm 0.05^{\mathrm{abcd}}$ \\
\hline $30 \%$ CF:70\%TF & $0.86 \pm 0.01^{a}$ & $0.51 \pm 0.07^{a b c}$ & $1.21 \pm 0.05^{b}$ & $4.77 \pm 0.01^{\mathrm{ab}}$ & $1.04 \pm 0.04^{b}$ & $0.89 \pm 0.03^{a b}$ & $1.62 \pm 0.06^{a b c}$ \\
\hline $20 \%$ CF: $80 \%$ TF & $0.80 \pm 0.02^{b}$ & $0.60 \pm 0.10^{a b}$ & $1.29 \pm 0.02^{\mathrm{ab}}$ & $5.30 \pm 0.02^{a}$ & $1.12 \pm 0.02^{\mathrm{ab}}$ & $0.94 \pm 0.05^{a}$ & $1.74 \pm 0.03^{a}$ \\
\hline $100 \% \mathrm{TF}$ & $0.81 \pm 0.03^{b}$ & $0.63 \pm 0.11^{a}$ & $1.54 \pm 0.05^{a}$ & $5.37 \pm 0.17^{a}$ & $1.31 \pm 0.10^{a}$ & $1.00 \pm 0.18^{a}$ & $1.67 \pm 0.07^{b c}$ \\
\hline
\end{tabular}

Values are means of triplicate determination.

Mean values with different superscripts within the same column are significantly different $(P<0.05)$.

CF - HQCF, TF - Tigernut flour. 
alkaloids are toxic. Some affect glucagon and thyroid stimulating hormones, while some have been reported to be carcinogenic (Okaka et al. 1992). They have also been used either as an analgesic, antispasmodic or bactericidal agents (Frantisek 1991).

The value of $1.47 \%$ saponin recorded by $100 \%$ tigernut flour used in this study was high compared to that (0.640.78) reported by Nwaoguikpe (2010). The saponin content of high quality cassava-tigernut flour blends ranged from $0.42 \pm 0.04$ to $1.24 \pm 0.06 \%$ while that of the extrudates ranged from $0.34 \pm 0.05$ to $1.31 \pm 0.10 \%$. Saponins have been reported to be useful in reducing inflammation of upper respiratory passage and also mainly as foaming and emulsifying agents (Frantisek 1991). It has also been found that saponin reduces the uptake of certain nutrients including glucose and cholesterol in the gut through intralumenal physicochemical interaction (Price et al. 1987).

The tannin content of high quality cassava-tigernut flour blends ranged from $3.62 \pm 0.04$ to $6.09 \pm 0.10 \%$ while that of the extrudates ranged from $2.46 \pm 0.10$ to $5.37 \pm 0.17 \%$. The tannin content of $100 \%$ tigernut flour $(6.04 \%)$ obtained in this study was low compared to the values (7.21-9.52\%) reported by Nwaoguikpe (2010). Nwaoguikpe (2010) worked on brown and yellow tigernut variety while only yellow variety was used in this study. Tannins have astringent properties that hasten the healing of wounds and prevention of decay. The phytate content of high quality cassava-tigernut flour blends ranged from $0.32 \pm 0.01$ to $1.90 \pm 0.02 \%$ while that of the extrudates ranged from $0.27 \pm 0.02$ to $1.54 \pm 0.05 \%$. The result obtained for phytate content of $100 \%$ tigernut flour (1.90\%) was lower than the values $(2.11-2.33 \%)$ reported by Nwaoguikpe (2010). The value obtained for $100 \%$ HQCF $(0.32 \%)$ was higher than the values $(0.22-0.30 \%)$ reported by Sarkiyayi and Agar (2010). The presence of phytates in biological systems may chelate divalent metals like calcium, magnesium, or block the absorption of essential minerals in the intestinal tract (Dan 2005). It would be expected that lowering these antinutritional compounds should enhance the bioavailability of such minerals as zinc and iron in the extrudates since phytic acid has been implicated in making these minerals unavailable (Anuonye et al. 2009). The reduction in these antinutrients can be explained by the partial degradation of the molecules of phytate. Although many findings have considered phytic acid as an antinutrient, recent findings have pointed out that phytic acid is an important antioxidant and additive, with applications in the manufacture of many novel food products such as pasta, bread, fish paste, meat, fruits and vegetables (Oatway et al. 2001; Batista et al. 2010).

\section{CONCLUSION}

The study showed that extrusion cooking reduced the antinutritional factors thereby increasing the bioavailabilty of minerals. Also, the minerals were not affected by the extrusion cooking process probably because minerals are heat stable. This implies that the usage of HQCF-tigernut flour blends and its extruded snacks for human food may not have any toxic effect to the consumers.

\section{ACKNOWLEDGMENT}

The authors wish to acknowledge funding provided by the EU Seventh Framework Programme to undertake this study.

\section{REFERENCES}

ADE-OMOWAYE, B.I.O., AKINWANDE, B.A., BOLARINWA, I.F. and ADEBUYI, A.O. 2008. Evaluation of tigernut (Cyperus esculentus) - Wheat composite flour and bread. Afr. J. Food Sci. 2, 87-91.

ANTON, A.A., FULCHER, R.G. and ARNTFIELD, S.D. 2009. Physical and nutritional impact of fortification of corn starch based extruded snacks with common bean (Phaseolus vulgaris L.) flour: Effects of bean addition and extrusion cooking. Food Chem. 113, 989-996.

ANUONYE, J. C. (2010). Effect of blending and extrusion on the physicochemical, nutritional and microbial quality of acha/soybeans mixtures, J. Sci. Tech. 16, 85-95.

ANUONYE, J.C., ONU, J.O., EGWIN, E. and ADEYEMO, S.O. 2009. Nutrient and anti nutrient composition of extruded acha/soybean blend. J. Food Process. Pres. 34, 680-691.

AOAC. 2000. Official Methods of Analysis, Association of Official Analytical Chemists, Washington, D.C.

BATISTA, K.A., PRUDÊNCIO, S.H. and FERNANDES, K.F. 2010. Changes in the functional properties and antinutritional factors of extruded hard-to-cook common beans (Phaseolus vulgaris, L.). J. Food Sci. 75, 286-290.

BELEWU, M.A. and BELEWU, K.Y. 2007. Comparative physiochemical evaluation of tigernut, soybean and coconut milk sources. Int. J. Agric. Biol. 5, 785-787.

BRUNNER, J.H. 1984. Direct spectrophotometric determination of saponin. Anal. Chem. 34, 1314-1326.

DAN, I. 2005. Health-fresh controversy over safety of soya bean. Punch Newspaper 26, 46.

DAY, R.A., JR. and UNDERWOOD, A.L. 1986. Quantitative Analysis, 5th ed., 701 pp., Prentice-Hall Publication, New Delhi.

DZIEDZOAVE, N.T., GRAFFHAM, A.J. and BOATENG, E.O. 2003. Training manual on the production of High quality cassava flour. Training Material Produced under the DFID-Funded Research Project (R7418) on 'New Market for Cassava', Accra, Ghana. 
DZIEDZOAVE, N.T., ABASS, A.B., AMOA-AWUA, W.K.A. and SABLAH, M. 2006. Quality Management Manual for Production of High Quality Cassava Flour, International Institute of Tropical Agriculture, Ibadan, Nigeria.

EMMANUEL, O.A., CLEMENT, A., AGNES, S.B., CHIWONA-KARLTUN, L. and DRINAH, B.N. 2012. Chemical composition and cyanogenic potential of traditional and high yielding CMD resistant cassava (Manihot esculenta Crantz) varieties. Int. Food Res. J. 19, 175-181.

ESSERS, A.A., BOSVEL, M., VAN DER GRIFT, R. and VORAGEN, A. 1993. Studies on the quantification of specific cyanogens in cassava products and introduction of a new chromogen. J. Sci. Food Agric. 63, 287-296.

ETESHOLA, E. and ORAEDU, A.C.I. 1996. Fatty acid composition of tigernut tubers (Cyperus esculentus L.), baobab seeds (Adasonia digitata L.) and their mixture. J. Am. Oil Chem. Soc. 73, 255-257.

EVANS, N.S. 2005. Trease and Evans. Pharmocognosy, 15th ed., pp. 1-24, Elsevier, New Delhi.

FALADE, K.O. and AKINGBALA, J.O. 2010. Utilization of cassava for Food. Food Rev. Int. 27, 51-83.

FRANTISEK, S.S. 1991. The Natural Guide to Medicinal Herbs and Plants, pp. 1-5, Tiger Barks Cast, Twinkemhan, UK.

HARBORNE, J.B. 1973. Phytochemical Methods, pp. 49-188, Chapman and Hall, Ltd., London.

HARPER, J.M. 1988. Effect of extrusion processing on nutrients In Nutritional Evaluation of Food Processing, 3rd ed. (E. Karmas and R.S. Harris, eds.) pp. 365-360, Van Nostrand Reinhold Company, New York.

IORGYER, M.I., ADEKA, I.A., IKONDO, N.D. and OKOH, J.J. 2009. The impact of boiling periods on the proximate composition and levels of some anti nutritional factors in Pigeon pea (Cajanus cajan) seeds. J. Agric. 5, 92-102.

KAREEM, S.T., ADEBOWALE, A.A., SOBUKOLA, O.P., ADEBISI, M.A., OBADINA, O.A., KAJIHAUSA, O.E., ADEGUNWA, M.O., SANNI, L.O. and KEITH, T. 2015. Some quality attributes of high quality cassava - Tigernut composite flour and its extruded snacks. J. Culinary Sci. Technol. 13, 242-262.

MAGA, J.A. 1982. Phytates: Its chemistry, occurrence, food interactions, nutritional significance and methods of analysis. J. Agric. Food Chem. 30, 1-7.

MALICK, C.P. and SINGH, M.B. 1980. Plant Enzymology and Histoenzymology, 286 pp., Kalyani Publications, New Delhi.

MARTIN-CABREJAS, M.A., SANFIZ, B., VIDAL, A., MOLLÁ, E., ESTEBAN, R. and LÓPEZ-ANDREU, F.J. 2004. Effect of fermentation and autoclaving on dietary fiber fractions and antinutritional factors of beans (Phaseolus vulgaris L.).

J. Agric. Food Chem. 52, 261-266.

MOUQUET, C., SALVIGNOL, B., VAN HOAN, N., MARVOIS, J. and TRECHE, S. 2003. Ability of a "very low cost extruder" to produce instant infant flours at a small scale in Vietnam. Food Chem. 82, 249-255.

MUREKATETE, N., HUA, Y. and IRAKOZE, P.C. 2010. Characterization of ready-to-eat composite porridge flours made by soy-maize-sorghum-wheat extrusion cooking process. Pak. J. Nutr. 9, 171-178.

NWAOGUIKPE, R.N. 2010. The phytochemical, proximate and amino acid compositions of the extracts of two varieties of tiger nut (cyperus esculentus) and their effects on sickle cell hemoglobin polymerization. J. Med. Med. Sci. 1, 543-549.

OATWAY, L., VASANTHAN, T. and HELM, J.H. 2001. Phytic acid. Food Rev. Int. 17, 419-431.

OBOH, G. and ROCHA, J.B.T. 2007. Polyphenols in red pepper [Capsicum annuum var. aviculare (Tepin)] and their protective effect on some pro-oxidants induced lipid peroxidation in brain and liver. Eur. Food Res. Technol. 225, 239-247.

OKAKA, J.C., ENOCH, N.J. and OKAKA, N.C. 1992. Human Nutrition: An Integrated Approach, pp. 57-58, ESUT Publications, Enugu.

OLADELE, A.K. and AINA, J.O. 2007. Chemical composition and functional properties of flour produced from two varieties of tigernut (Cyperus esculentus). Afr. J. Biotechnol. 6, 2473-2476.

OLADELE, K.A., OSUNDAHUNSI, F.O. and ADEBOWALE, A.Y. 2009. Influence of processing techniques on the nutrients and anti-nutrients of tigernut (Cyperus esculentus L.). World J. Dairy Food Sci. 2, 88-93.

OMEIRE, G.C., IWE, M.O. and UCHECHUKWU, N. 2012. Effect of extrusion variables on the hydrogen cyanide and haemagglutinin content of extruded blends of cassava products and african yam bean. Food Sci. Qual. Manage. 6, 23-33.

PRICE, K.R., JOHNSON, L.I. and FERIWICK, H. 1987. The chemical and biological significance of saponins in foods and feeding stuffs. Crit. Rev. Food Sci. Nutr. 26, 27-135.

SANNI, L.O., MAZIYA-DIXON, B., AKANYA, J., OKORO, C.I., ALAYA, Y., EGWUONWU, C.V., OKECHUKWU, R., EZEDINMA, C., AKORODA, M., LEMCHI, J., ET AL. 2005. Standards for Cassava Products and Guidelines for Export, 93 pp., IITA, Ibadan, Nigeria.

SANNI, L.O., ADEBOWALE, A.A., MAZIYA-DIXON, B. and DIXON, A.G.O. 2008. Chemical composition and pasting properties of CMD resistant cassava clones planted at different locations. J. Food Agric. Environ. 6, 97-104.

SARKIYAYI, S. and AGAR, T.M. 2010. Comparative analysis on the nutritional and anti-nutritional contents of the sweet and bitter cassava varieties. Adv. J. Food Sci. Technol. 2, 328-334.

SAVAGE, G.P. 1993. Saponins. In Encyclopedia of Food Science, Food Technology and Nutrition (R. Macre, R.K. Robinson and M.J. Sadler, eds.) pp. 3998-4001, Academic Press, London.

SHIMELIS, E.A. and RAKSHIT, S.K. 2007. Effect of processing on antinutrients and in vitro digestibility of kidney bean (Phaseolus vulgaris L.) varieties grown in East Africa. Food Chem. 103, 161-172. 
SOBUKOLA, O.P., BABAJIDE, J.M. and OGUNSADE, O. 2012. Effect of brewer speent grain addition and extrusion parameters on some properties of extruded yam starch-based pasta. J. Food Process Pres. 37, 1745-1749.

SOFOWORA, E.A. 1993. Medicinal Plants and Traditional Medicine in Africa, Ibadan-Owerri-Kaduna-Lagos Spectrum Books Limited, pp. 159-238.

SWAIN, T. 1979. Tannins and lignins. In Herbivores, Their Interaction With Secondary Plant Metabolites (G.A. Rosenthal and D.H. Jansen, eds.) pp. 6574-6574, Academic Press, New York.

THOMAS, M.D. 2006. Textbook of Biochemistry, 6th ed., pp. 1080-1084, John Wiley and Sons Ltd., New York.

TSEGAI, D. and KORMAWA, P.C. 2002. Determinants of Urban Household Demand For Cassava Products in Kaduna, Nigeria. In Conference of International Research for Development, Witzenhause, 9-10 October 2002. 